\title{
Gill erosion and herpesvirus in Crassostrea gigas cultured in Baja California, Mexico
}

\author{
Rebeca Vásquez-Yeomans ${ }^{1,2}$, Mauricio García-Ortega ${ }^{2}$, Jorge Cáceres-Martínez ${ }^{1,2, *}$ \\ ${ }^{1}$ Centro de Investigación Científica y de Educación Superior de Ensenada. CICESE. Km 107 Carretera Ensenada-Tijuana \\ 3918 Zona Playitas, CP 22860, Ensenada, Baja California, México \\ ${ }^{2}$ Instituto de Sanidad Acuícola, A. C. ISA. Calle 15 \#265, entre Obregón y Moctezuma, CP 22800, Ensenada, Baja California, \\ México
}

\begin{abstract}
Recurrent episodes of mortality of Crassostrea gigas cultured in northwestern Mexico have been occurring since 1997. Previous studies on bacteria, protozoans, and metazoans as presumptive causal agents have been inconclusive. However, erosions in the marginal indentation of gills have been frequently observed in oysters from areas affected by mortality events, and in 2000 those lesions were associated with the detection of a herpes-like virus. The present study aimed to describe the histological alterations of eroded gills and to determine whether ostreid herpesvirus 1 (OsHV-1) or a related virus was associated with them using in situ hybridization (ISH). Histology showed that gill filaments were fused. In severe cases, deformation of the interlamellar junctions, swelling, and the loss of water channels was observed. ISH analysis revealed the presence of OsHV-1 DNA or a related virus in cells of the gills. Some labeled cells were large with dark granules inside their cytoplasm. These cells were surrounded by infiltrating hemocytes. Some cells interpreted as hemocytes were labeled and observed in eroded and non-eroded areas of the gill. Large cells detected by ISH were also observed by conventional histology with hematoxylin-eosin staining. Whether the virus produces the erosions in the gills, or the erosions in the gills are produced by an unknown condition and favor the presence of the virus, remains unresolved. It is also not clear whether the lesions contribute to mortality.
\end{abstract}

KEY WORDS: Crassostrea gigas $\cdot$ OsHV-1 $\cdot$ Herpesvirus $\cdot$ Gill erosion · Oyster mortality Resale or republication not permitted without written consent of the publisher

\section{INTRODUCTION}

Since 1997, several episodes of unexplained mortalities of cultured Pacific oyster Crassostrea gigas have occurred in Baja California and other localities in northwestern Mexico (Cáceres-Martínez 2000, Correa et al. 2004, Cáceres-Martínez et al. 2004). Studies focused on bacteria, protozoans, and metazoans as the causal agent(s) have been reported (Cáceres-Martínez et al. 1998, Cáceres-Martínez \& Vásquez-Yeomans 2003, Vásquez-Yeomans et al. 2004a), but none of these agents seemed to be directly related to the mortalities. However, gill erosions have commonly been observed in juvenile and adult oysters from mortality outbreak areas. These erosions were associated with giant polymorphic cells and a virus (Cáceres-Martínez \& Vásquez-Yeomans 2003), resembling the gill necrosis virus disease (GNV) of C. angulata and C. gigas caused by an irido-like virus in Europe during the 1960s (Comps 1988). Recent studies using transmission electron microscopy (TEM) in eroded gill tissue revealed the presence of a herpes-like virus, not an iridolike virus (Vásquez-Yeomans et al. 2004b), although giant polymorphic cells were not observed.

Herpes-like virus and herpesvirus infections associated with high mortality episodes have been reported in larvae, spat, and juveniles of bivalve mollusks including Crassostrea gigas (Hine et al. 1992, Nicolas 
et al. 1992, Comps \& Cochennec 1993, Renault et al. 1994a,b, Friedman et al. 2005). Descriptions of tissue damage in C. gigas larvae indicate that the lesions are confined to the connective tissues (Hine et al. 1992, Nicolas et al. 1992, Renault et al. 2001a,b). Similarly, the most evident histological alteration in C. gigas spat is the presence of abnormal nuclei throughout the connective tissue (Renault et al. 1994a,b, 2000). In juveniles of $C$. gigas infected by an oyster herpesvirus, hemocyte degeneration characterized by nuclear pycnosis and fragmentation have been reported (Friedman et al. 2005).

Although herpes-like viruses and herpesviruses have also been detected in adult Crassostrea virginica (Farley et al. 1972), Ostrea angasi (Hine \& Thorne 1997), C. gigas (Arzul et al. 2002, Vásquez-Yeomans et al. 2004b), and O. edulis (Da Silva et al. 2008), descriptions of histological alterations associated with this virus in adult oysters are lacking. Da Silva et al. (2008) described the presence of abnormal cells in only 1 adult oyster; these cells had hypertrophied nuclei with marginated chromatin and a characteristic large intranuclear acidophilic inclusion and were observed throughout the connective tissue of the visceral mass, gills, labial palps, and mantle.

Contrary to observations made in larvae and spat, adult oysters appear less sensitive to ostreid herpesvirus 1 (OsHV-1; Arzul et al. 2002, Da Silva et al. 2008). Arzul et al. (2002) detected OsHV-1 in adult Crassostrea gigas with normal appearance, using polymerase chain reaction (PCR), in situ hybridization (ISH), and immunochemistry using polyclonal antibodies, and concluded that OsHV-1 infects adult C. gigas with high prevalence and that the virus may persist in the host after primary infection. Those authors did not mention any alteration of gill tissue. However, histological changes in gills of adult oysters associated with a herpes-like virus have been described (Cáceres-Martínez \& Vásquez-Yeomans 2003, Vásquez-Yeomans et al. 2004b). Several questions arise from this knowledge, including: What are the characteristics of gill erosions at the histological level? Are the gill erosions found in oysters from mortality outbreak areas in Mexico related to OsHV-1 or a related virus? The objectives of this study were to provide a histological description of the gill erosions and to determine whether those erosions are related to OsHV-1 or to a related virus using ISH.

\section{MATERIALS AND METHODS}

Oyster sampling. In September 2000, we obtained a total of 30 cultured Pacific oysters Crassostrea gigas (size range 100 to $120 \mathrm{~mm}$ ) from producers in Bahía de San Quintín, Baja California $\left(30^{\circ} 24^{\prime}\right.$ to $30^{\circ} 30^{\prime} \mathrm{N}$ and $115^{\circ} 57^{\prime}$ to $116^{\circ} 01^{\prime} \mathrm{W}$ ), where mortality outbreaks had previously been reported. This sample size was dependent on the availability of oysters from producers, and a similar number has been used in studies on herpesvirus detection (Arzul et al. 2002). Live oysters were sent to the Centro de Investigación Científica y de Educación Superior de Ensenada. All fouling organisms were removed with a brush in a stream of seawater. Oysters were placed in a Petri dish, opened, and each gill was examined for the presence of erosions in the marginal indentation of the gill (Fig. 1). Estimation of the prevalence of gill erosion was considered as the number of affected oysters per number of oysters examined $\times 100$. Intensity of the erosions was evaluated as moderate (1), medium (2), and severe (3) according to the intensity of erosion in the marginal indentation of the gill (Fig. 1). Oysters were separated according to the intensity of gill erosion, and 2 individuals representing each degree of gill erosion were used for histology and ISH analyses. The gills of 1 oyster without gill erosions were used as a control.

Histopathology. Gill pieces were fixed in Davidson's fixative (Shaw \& Battle 1957) for at least $24 \mathrm{~h}$ and were embedded in paraffin wax after fixation. From each

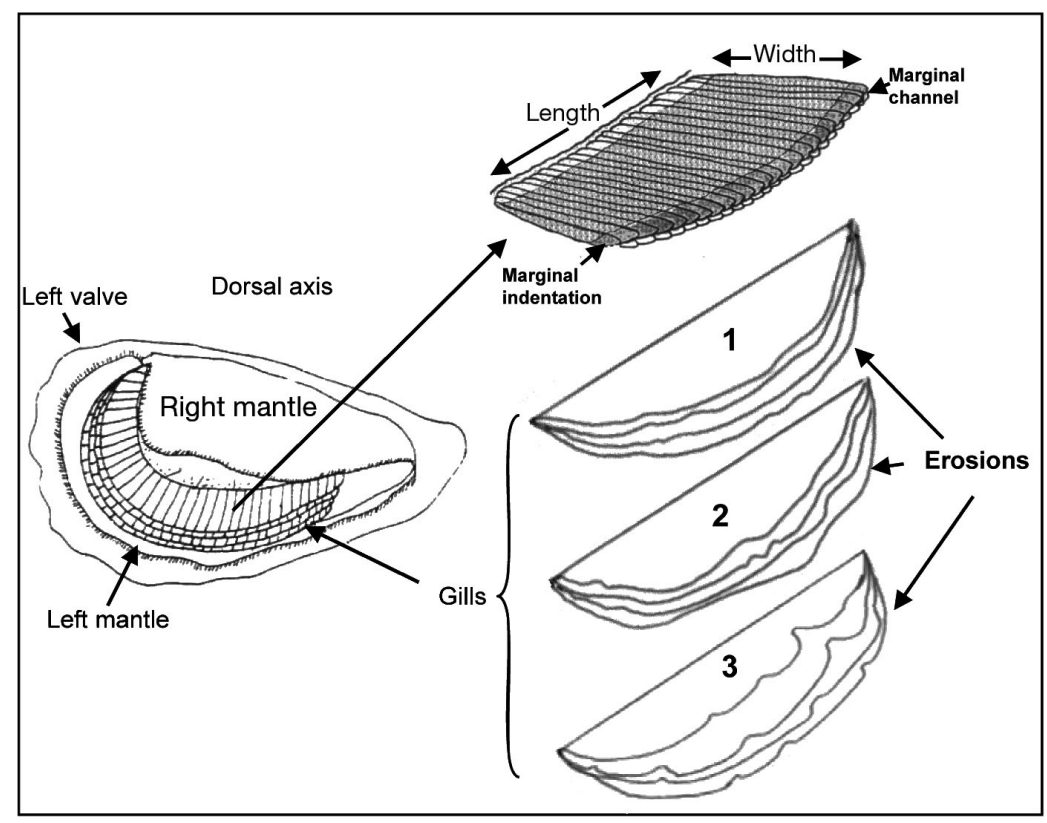

Fig. 1. Crassostrea gigas. Exposed gills showing the marginal indentation of the lamellae where erosion takes place, altering its normal architecture. Gill lamellae showing intensity of gill erosion: (1) moderate, (2) medium, and (3) severe (modified from Comps 1970 and Brun et al. 1999) 
paraffin block, 2 slides were obtained. One was stained with hematoxylin-eosin (Shaw \& Battle 1957) for conventional histology analysis and the other was used for ISH as described below.

In situ hybridization. ISH was performed using a modification of the protocol described by Arzul et al. (2002) designed to detect OsHV-1 DNA with the following changes: (a) primers $\mathrm{C} 2$ and $\mathrm{C} 6$ were labeled with digoxigenin-11-dUTP (Invitrogen) and were used as probes; (b) $5 \mu \mathrm{m}$ thick tissue sections were used; (c) the tissues were equilibrated in buffer I and blocked with buffer I containing $1 \%$ sterile sheep serum (Chemicon International) at room temperature for $30 \mathrm{~min}$; (d) slides were incubated with substrate solution $\left(370 \mu \mathrm{g} \mathrm{\mu l}^{-1}\right.$ nitroblue

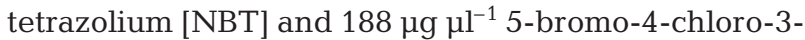

indolyl phosphate [BCIP] in buffer II; Roche Diagnostics) for $30 \mathrm{~min}$ in the dark at room temperature, and (e) slides were mounted in resin Cytoseal ${ }^{\mathrm{TM}} 60$ (Richard-Allan Scientific).

\section{RESULTS}

Histology of gill erosions. Prevalence of gill erosions was $30 \%$; of these, $30 \%$ corresponded to moderate, $50 \%$ to medium, and $20 \%$ to severe erosions. The histopathological analysis shows a series of changes in the eroded areas, with moderate erosions starting with fusion of the tops of the gill filaments changing the architecture of marginal indentation
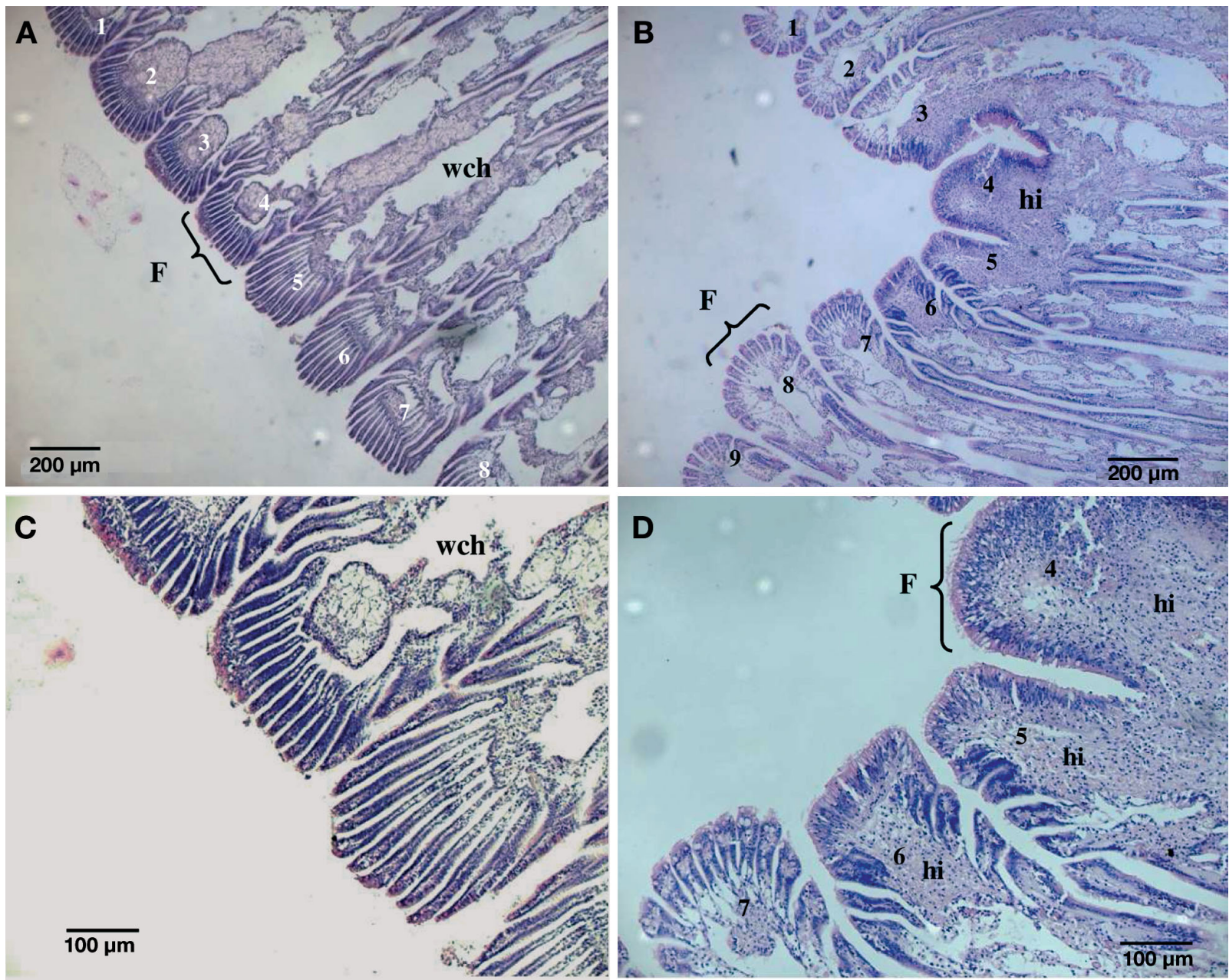

Fig. 2. Crassostrea gigas. Histological comparison of the gill lamellae of healthy oysters (A,C) and lamellae with medium erosion $(B, D)$. (A) Panoramic view of 8 filaments (F) with wide water chambers (wch) and normal apices, which correspond to a uniform marginal indentation. (B) Panoramic view of 9 filaments (F) showing shortening and torsion through the center. A hemocyte infiltration (hi) is shown in central filaments $(3,4,5)$. Comparison at higher magnification is shown in (C) and (D). Thin filaments, a light hemocyte accumulation, and wide water chambers (wch) from a healthy oyster are shown in (C). In contrast to this, in (D) shortening and thickening of the filament apices is shown. There is a fusion of filament apices and hemocyte infiltration, which is major in filament number 1 having lost the normal apical architecture. No large cells with dark granules in cytoplasm are observed. Hematoxylin-eosin stain 
and marginal channel (Fig. 2A,B). Fusion resulted in gill filaments losing their individuality and increased the number of hemocytes in affected filaments (Fig. 2B). Shortening of joined filaments produced torsion of neighboring healthy filaments resulting in a crack (Fig. 2B,D). The water channels in affected filaments decreased in volume due to accumulation of hemocytes (swelling) and due to the shortening of the filaments (Fig. 2B,D). When erosion increases, hemocyte accumulation also increases, causing swelling and the entire loss of the normal architecture of the plicas of the gill including deformation of the interlamellar junctions and the loss of water channels (Figs. 3A-D \& 4). In some cases, large cells with dark granules inside of the cytoplasm were observed (Fig. 5A). Detailed observation shows the total loss of the normal filament epithelia and mitotic figures (Fig. 3A-D). No pycnosis, karyorrhexis, or Cowdry type A viral inclusions were observed. Severely eroded lamellae have a jagged appearance.

In situ hybridization. In all eroded gills studied (moderate, medium, and severe), there was a positive labeling of the probe. In some eroded areas, a singular labeled large cell with dark granules, corresponding to those observed by classical histology mentioned above (Fig. 5A,B), was observed. These large cells were more abundant in severely eroded gills. In this case, they were scattered through the connective tissue, which was infiltrated by hemocytes (Fig. 6A). There was no clear difference in the signal of the probe in the nucleus and cytoplasm of large cells (Fig. 6C,D). In some cases, labeled cells interpreted as hemocytes were detected close to large cells. Some of these showed a weak reaction to ISH (Fig. 6B). In other cases, an intense reaction to ISH in the cytoplasm of cells was observed in fused filaments from eroded areas or in normal filaments
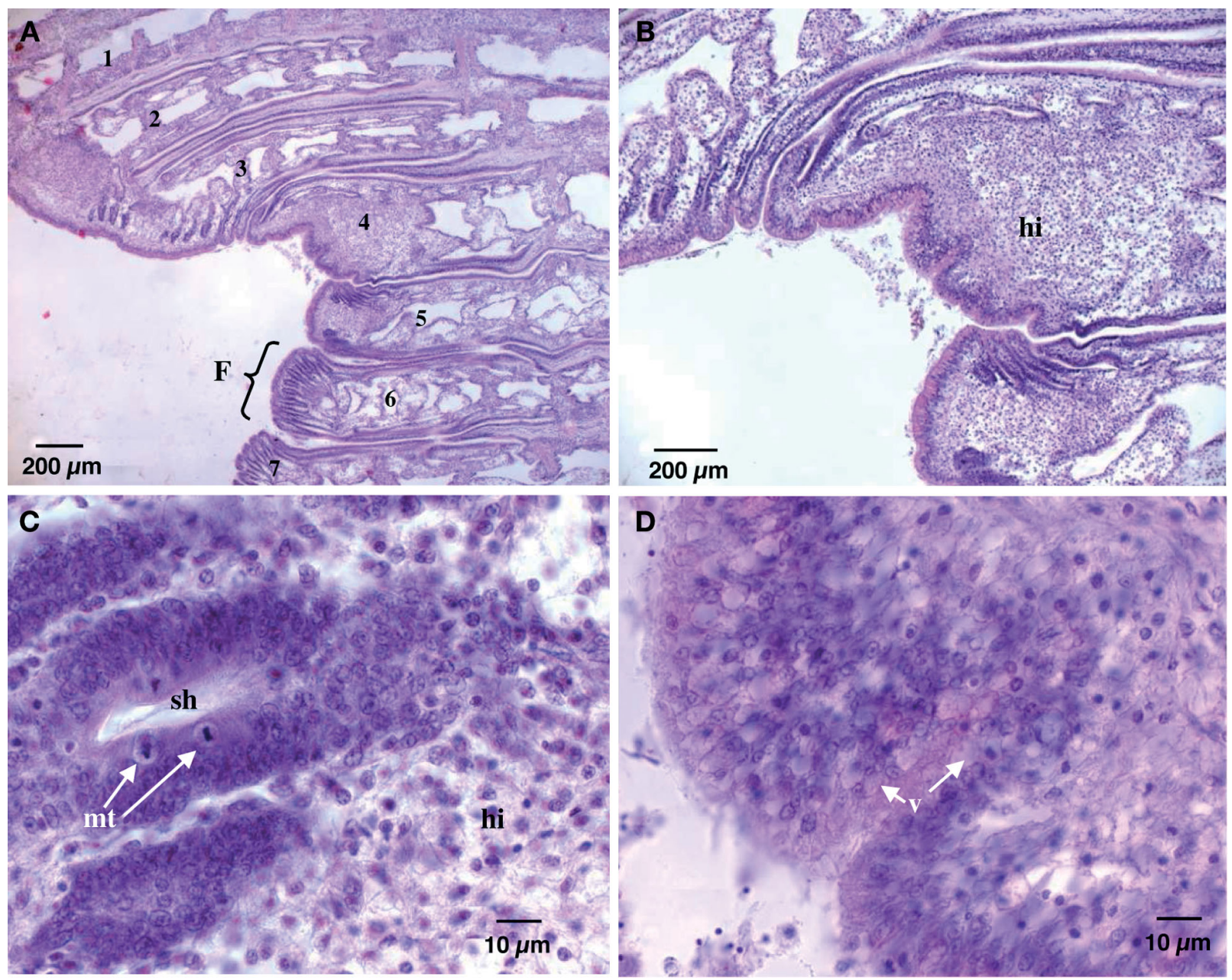

Fig. 3. Crassostrea gigas. Marginal indentation of severely eroded gill lamellae of oysters. (A) Panoramic view of 7 filaments (F) showing the entire fusion of filaments 1, 2, 3, and 4 . Apices of filaments 5, 6, and 7 are in the process of fusion. (B) Hemocyte infiltration (hi) and destruction of the normal architecture of the gill edge. (C) Hemocyte infiltration (swollen) and obstruction of the hemolymphatic sinus of the filament (sh) and presence of mitotic figures (mt). (D) Swollen edge of an eroded gill with abundant vacuoles (v). Hematoxylin-eosin stain 


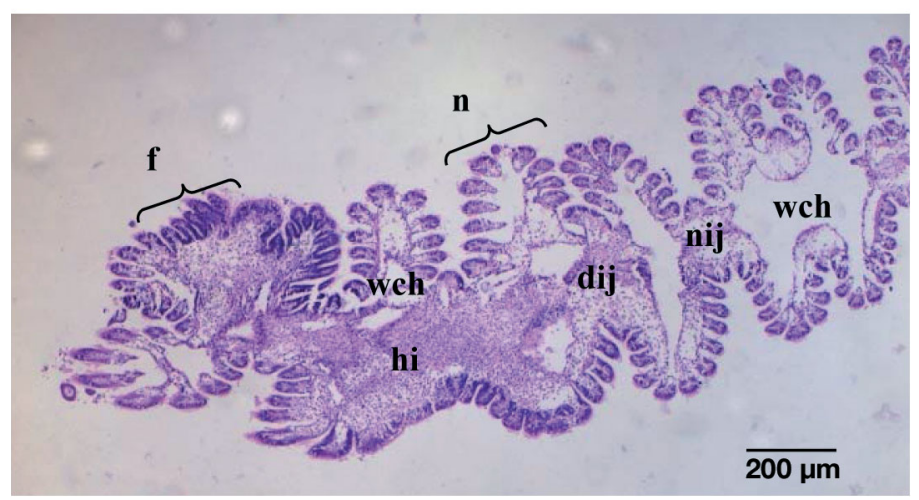

Fig. 4. Crassostrea gigas. Transversal cut of an eroded filament where normal (n) and fusionate (f) plicas are shown in the apical area of the filament. Hemocyte infiltration (hi) is shown. Interlamellar junctions are deformed (dij). The water chambers (wch) in the eroded edge have disappeared or have been reduced, while in the normal area there are wide water chambers (wch) and the interlamellar junctions are normal (nij). Hematoxylin-eosin stain

(Fig. 7A,B). In non-eroded gills (negative control), no hemocyte infiltration or labeled cells were observed (Fig. 8A,B).

\section{DISCUSSION}

That $30 \%$ of the oysters showed gill erosions indicates a high prevalence of lesions in the study area, where mortality outbreaks may reach around 60\% according to oyster producers. On the other hand, only 2 individuals showed severe gill erosion. Future studies should be designed to better assess the prevalence and intensity of lesions over time as well as their association with mortality records.

Since the description of GNV disease in the Portuguese oyster Crassostrea angulata and the Pacific oyster C. gigas by Comps (1980), few reports have focused on the possible link between gill lesions and viral infection. Da Silva et al. (2006) described extensive lesions in the gills of the flat oyster Ostrea edulis characterized by hemocytic infiltration and loss of branchial architecture. Abundant apoptotic hemocytes were found, but no etiological agent was detected. Oysters did not exhibit external signs of gill injury under macroscopic examination except for 1 individual that had some indentations. Fusion of apical filaments was not mentioned.

Records of herpes-like virus or herpesvirus as a causal agent of mortality in Crassostrea gigas larvae do not mention gill erosion (Hine et al. 1992, Nicolas et al. 1992, Renault et al. 2001a,b, Friedman et al. 2005). Histological changes described include fibroblastic-like cells exhibiting abnormal cytoplasmic basophilia and enlarged nuclei with marginated chromatin. Other cells, interpreted as hemocytes, showed extensive chromatin condensation. These cells were present throughout the connective tissues, especially in the mantle, labial palps, gills, and digestive gland of the spat (Renault et al. 1994a,b, 2000). Friedman et al. (2005) described hemocytosis, diapedesis, and hemocyte degeneration characterized by nuclear pycnosis and fragmentation in juvenile $C$. gigas infected with an oyster herpesvirus. In adult $C$. gigas infected by OsHV-1, there was no noticeable tissue alteration, suggesting that infected adults could be asymptomatic carriers (Arzul et al. 2002, Renault \& Novoa 2004). Furthermore, the herpesvirus was not detected in hemocytes of adult C. gigas (Arzul et al. 2002). In contrast, our results showed OsHV-1 or a related virus in large cells of eroded areas of the gills and in cells, interpreted as hemocytes, from eroded and non-eroded gill tissue in adult C. gigas. This finding agrees with Hine \& Thorne (1997), who found a herpes-like virus present in hemocytes of adult
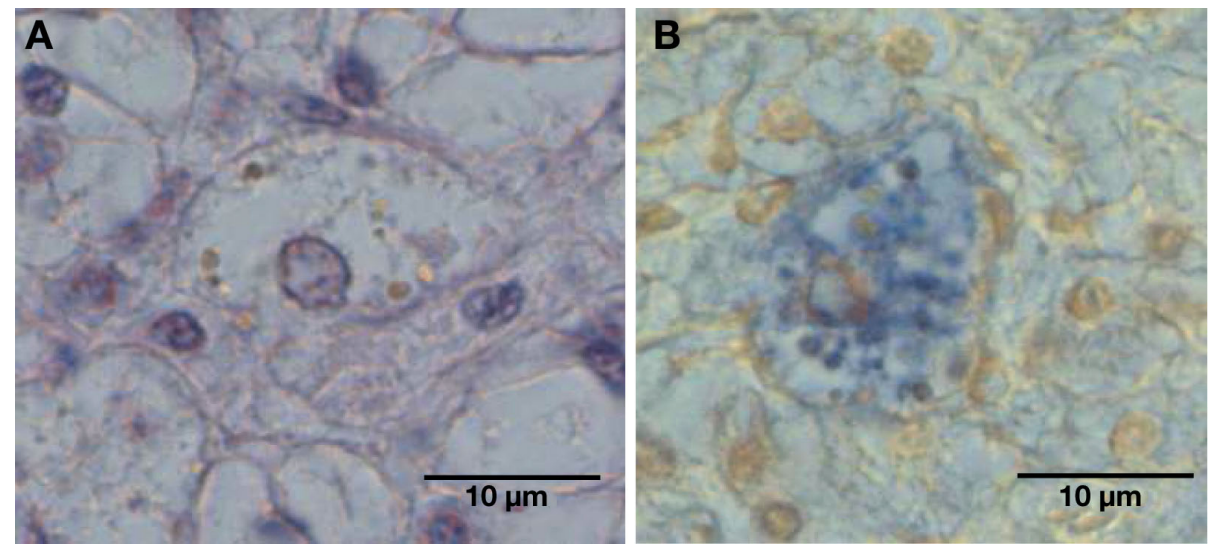

Fig. 5. Crassostrea gigas. (A) Large cell in connective tissue of the gill stained with hematoxylin-eosin. (B) Large cell in connective tissue of the gill positive by in situ hybridization 

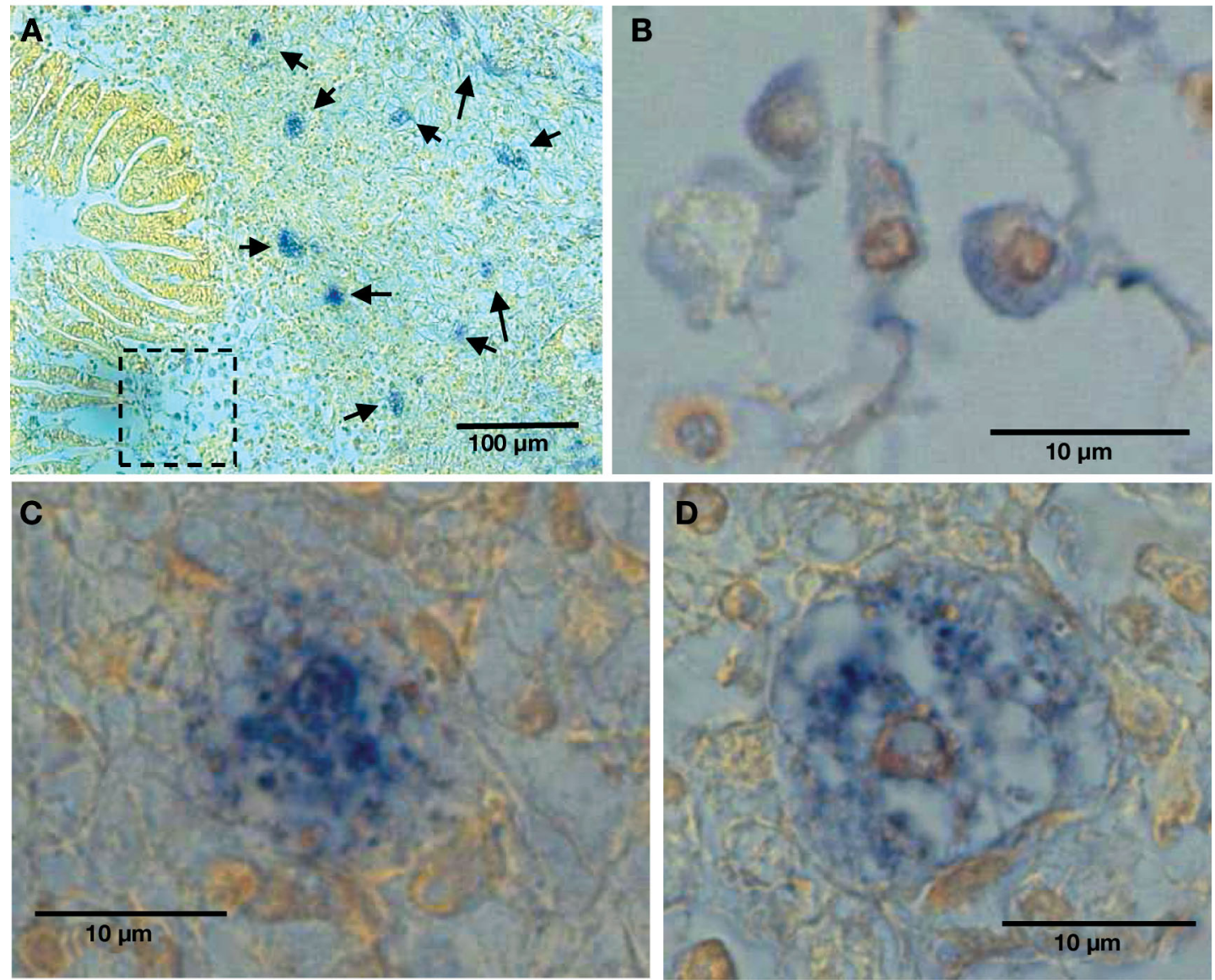

Fig. 6. Crassostrea gigas. In situ hybridization results characterized by purple precipitates indicating a positive reaction to OsHV-1 or a related virus. (A) General view of inflammation in the connective tissue of an eroded gill showing several labeled large cells (arrows). (B) Close-up of framed area showing cells interpreted as hemocytes with a weak signal to OsHV-1 or a related virus in the cytoplasm. (C) Large cell with positive staining in the cytoplasm and apparently in the nucleus. (D) Large cell with positive labeling in the cytoplasm
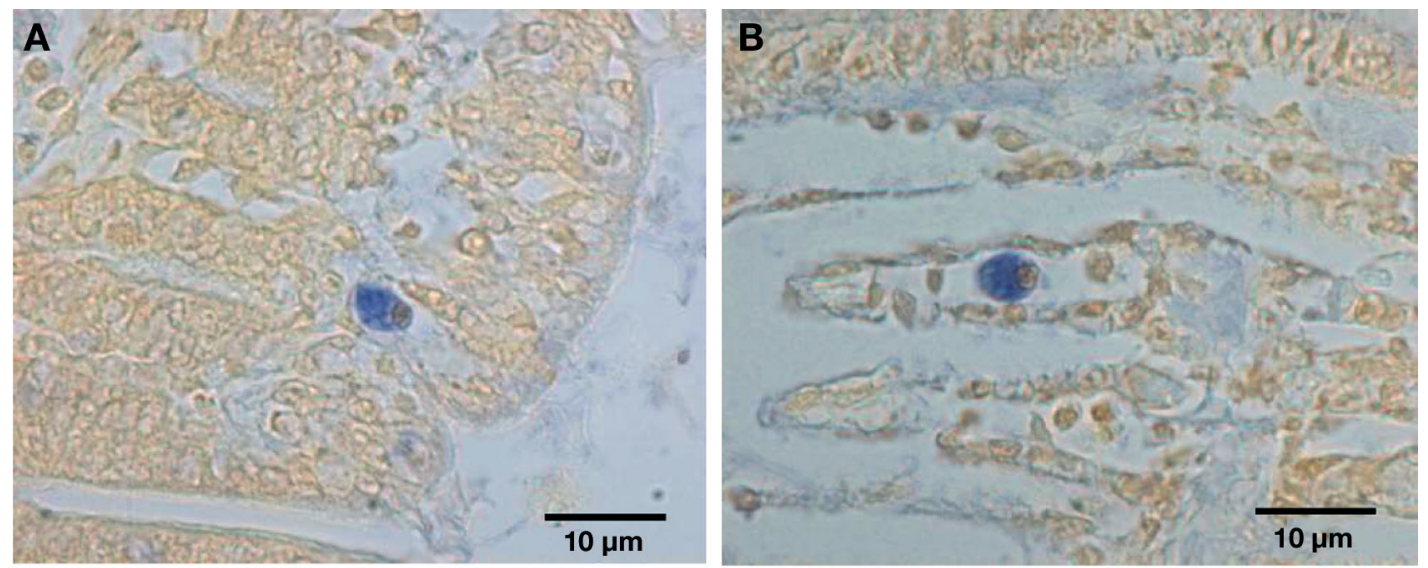

Fig. 7. Crassostrea gigas. In situ hybridization of eroded and non-eroded areas of the gill. (A) Cell interpreted as a hemocyte showing a clear positive reaction to OsHV-1 or a related virus in the cytoplasm from the epithelial tissue of fused gill filaments in the marginal indentation of the eroded gill. (B) Cell interpreted as a hemocyte showing a clear positive reaction to OsHV-1 or a related virus in the cytoplasm from a normal gill filament 

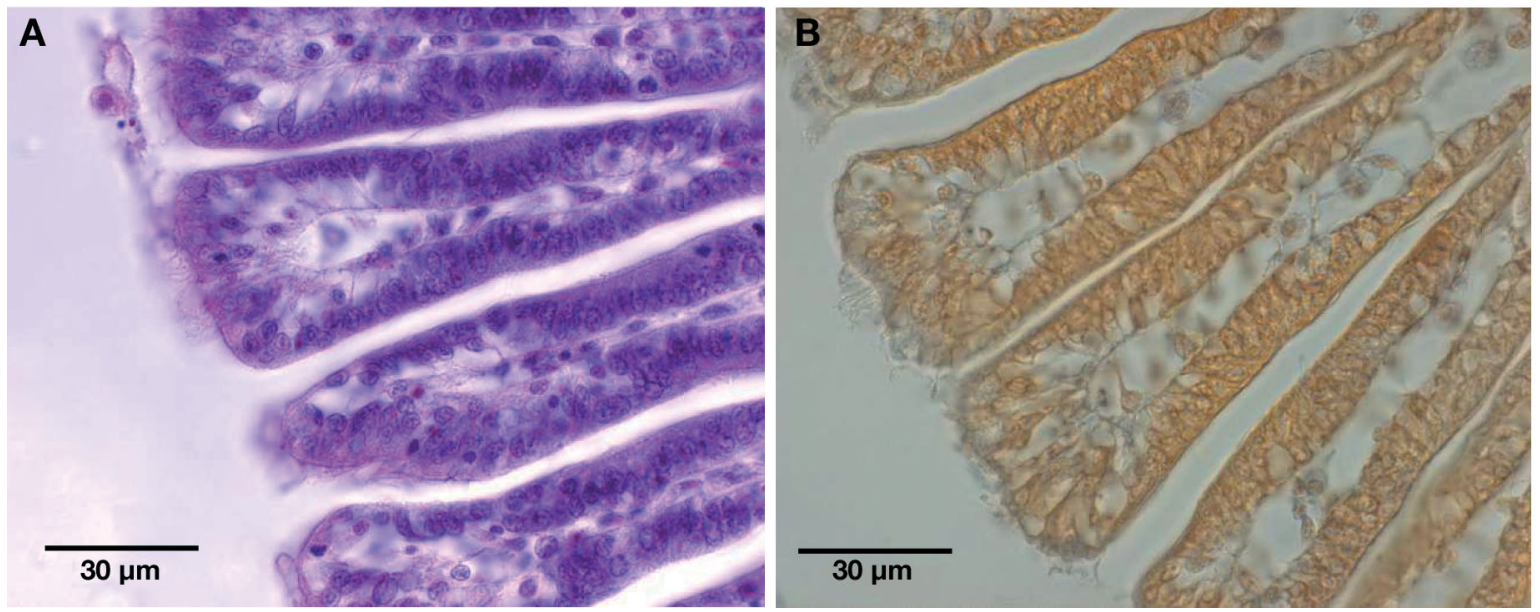

Fig. 8. Crassostrea gigas. Conventional histology using hematoxylin-eosin staining and in situ hybridization of healthy noneroded gills. (A) General view of a non-eroded marginal indentation of the gill, showing a normal architecture without hemocyte infiltration or large cells. (B) Similar plane of non-eroded marginal indentation of the gill showing a negative reaction to OsHV-1 or a related virus

Ostrea angasi. Although we could successfully detect OsHV-1 or a related virus by targeting a single genome area, the use of more genome areas could improve the detection of this virus.

Detection of labeled cells in the connective tissue of the eroded gills agrees with the presence of OsHV-1 or a related virus in the connective tissue of larvae, spat, and juveniles of Crassostrea gigas as mentioned above. ISH-positive results have been observed in different organs such as gills of OsHV-1-infected C. gigas spat (Lipart \& Renault 2002). Descriptions of infections in larvae, spat, and juveniles do not mention large cells with dark granules inside the cytoplasm, which we observed in adults. However, the presence of yellowish material has been documented in juveniles (Webb et al. 2007). Voyles (2002) associated this kind of cell alteration with a process of destruction of the host cell by the viruses. In our study, the positive signal of the probe observed more clearly in the cytoplasm than in the nucleus may correspond to viral DNA from degraded virus particles after internalization by hemocytes; in such cases, the hemocytes are not infected. This also allows us to hypothesize that adult oysters have mechanisms for destroying the virus, which seem not to occur in larvae, spat, and juvenile oysters, and is in agreement with findings for adult oysters that seem to be less sensitive to OsHV-1 (Arzul et al. 2002, Da Silva et al. 2008).

Why were the signs of eroded gills not observed in other areas where this virus has been studied? It could be related to the strain of virus, to the interaction of the herpesvirus and host in a particular environment, susceptibility of the host, and other unknown causes. Additionally, there is no complete evidence about
OsHV-1 or a related virus being directly responsible for gill erosion, or that gill erosion caused by unknown environmental or biological agents favors the presence of the virus.

Observed gill erosions are limited to the area close to the marginal indentation, which suggests that the function of the gill could be not entirely damaged. Additional studies are necessary to determine whether OsHV-1 or a related virus reaches the connective tissue of the host in other parts of its body, which would suggest major potential damage that could result in mortality of the host. Other questions arising include: Are the gill erosions of oysters the cause of mortality outbreaks? Or, are they common non-lethal lesions in apparently healthy carriers? Further studies are necessary to answer these questions.

Acknowledgements. We thank T. Renault and I. Arzul from IFREMER for valuable comments about ISH results. This work was carried out with the financial support of CICESE, ISA, and the Produce Foundation (project no. 02-2005-0185).

\section{LITERATURE CITED}

Arzul I, Renault T, Thebault A, Gerard A (2002) Detection of oyster herpesvirus DNA and proteins in asymptomatic Crassostrea gigas adults. Virus Res 84:151-160

Brun NT, Boghen AD, Allard J (1999) Distribution of the turbellarian Urastoma cyprinae on the gills of the eastern oyster Crassostrea virginica. J Shellfish Res 18:175-179

Cáceres-Martínez J (2000) Resultados de los análisis patológicos efectuados a ostiones del pacífico relacionados con mortalidades masivas. Foro regional sobre la problemática del cultivo de moluscos bivalvos en el noroeste de México. Universidad de Sonora, Hermosillo, Sonora, México

Cáceres-Martínez J, Vásquez-Yeomans R (2003) Presence of giant polymorphic cells in Crassostrea gigas cultured in 
Bahia Falsa, Baja California NW México. J Shellfish Res 22:711-714

Cáceres-Martínez J, Macías-Montes de Oca P, VásquezYeomans R (1998) Polydora sp. infestation and health in the Pacific oyster Crassostrea gigas cultured in Baja California, NW México. J Shellfish Res 17:259-264

Cáceres-Martínez J, Curiel-Ramírez GS, Vásquez-Yeomans R, Macías-Montes de Oca P (2004) Reproductive cycle and mortality of the Japanese oyster Crassostrea gigas cultured in Bahía Falsa, Baja California, México. J Shellfish Res 23:795-801

Comps M (1970) La maladie des branchies chez les huîtres du genre Crassostrea. Caractéristiques et évolution des altérations, processus de cicatrisation. Rev Trav Inst Pech Marit 34:23-44

Comps M (1980) Les infections virales associées aux épizooties des huîtres du genre Crassostrea. ICES Spec Meet Dis Comm Imp Mar Fish Shellfish, Copenhagen, No. 6

Comps M (1988) Epizootic diseases of oysters associated with viral infections. In: Fisher WS (ed) Disease processes in marine bivalve molluscs. Spec Publ Am Fish Soc 18, Bethesda, MD, p 23-37

Comps M, Cochennec N (1993) A herpes-like virus from the European oyster Ostrea edulis L. J Invertebr Pathol 62: 201-203

Correa F, Collins E, Oceguera A, Cordero B, Domínguez D (2004) Variación alozímica del ostión Japonés Crassostrea gigas en Bahía San Quintín, Baja California, México. Cienc Mar 30:89-97

Da Silva PM, Villalba A, Sunila I (2006) Branchial lesions associated with abundant apoptotic cells in oysters Ostrea edulis of Galicia (NW Spain). Dis Aquat Org 70:129-137

Da Silva PM, Reault T, Fuentes J, Villalba A (2008) Herpesvirus infection in European flat oysters Ostrea edulis obtained from brood stocks of various geographic origins and grown in Galicia (NW Spain). Dis Aquat Org 78: 181-188

Farley CA, Banfield WG, Kasnic JRG, Foster WS (1972) Oyster herpes-type virus. Science 178:759-760

Friedman CS, Estes RM, Stokes NA, Burge CA and others (2005) Herpes virus in juvenile Pacific oysters Crassostrea gigas from Tomales Bay, California, coincides with summer mortality episodes. Dis Aquat Org 63:33-41

Hine PM, Thorne T (1997) Replication of herpes-like viruses in hemocytes of adult flat oysters Ostrea angasi: an ultrastructural study. Dis Aquat Org 29:189-196

Editorial responsibility: Mike Hine, Fouras, France
Hine PM, Wesney B, Hay BE (1992) Herpesviruses associated with mortalities among hatchery-reared larval Pacific oysters Crassostrea gigas. Dis Aquat Org 12:135-142

Lipart C, Renault T (2002) Herpes-like virus detection in infected Crassostrea gigas spat using DIG-labelled probes. J Virol Methods 101:1-10

Nicolas JL, Comps M, Cochennec N (1992) Herpes-like virus infecting Pacific oyster larvae Crassostrea gigas. Bull Eur Assoc Fish Pathol 12:11-13

Renault T, Novoa B (2004) Viruses infecting bivalve molluscs. Aquat Living Resour 17:397-409

Renault T, Cochennec N, Le Deuff RM, Chollet B (1994a) Herpes-like virus infecting Japanese oyster (Crassostrea gigas) spat. Bull Eur Assoc Fish Pathol 14:64-66

Renault T, Le Deuff LM, Cochennec N, Maffart P (1994b) Herpesviruses associated with mortalities among Pacific oyster, C. gigas in France-comparative study. Rev Med Vet 145:735-742

Renault T, Le Deuff LM, Chollet B, Cochennec N, Gérard A (2000) Concomitant herpes-like virus infections in hatchery-reared larvae and nursery-cultured spat Crassostrea gigas and Ostrea edulis. Dis Aquat Org 42:173-183

Renault T, Lipart C, Arzul I (2001a) A herpes-like virus infects a non-ostreid bivalve species: virus replication in Ruditapes philippinarum larvae. Dis Aquat Org 45:1-7

Renault T, Lipart C, Arzul I (2001b) A herpes-like virus infecting Crassostrea gigas and Ruditapes philippinarum larvae in France. J Fish Dis 24:369-376

> Shaw BL, Battle IH (1957) The gross microscopic anatomy of the digestive tract of the oyster Crassostrea virginica (Gmelin). Can J Zool 35:325-346

Vásquez-Yeomans R, Cáceres-Martínez J, García-Ortega M (2004a) Identificación de bacterias aisladas de las branquias del ostión Japonés Crassostrea gigas cultivado en Bahía Falsa, B. C., México durante un episodio de mortalidad. Anal Inst Biol UNAM Ser Zool 75:237-243

Vásquez-Yeomans R, Cáceres-Martínez J, Figueras A (2004b) Herpes-like virus associated with eroded gills of the Pacific oyster Crassostrea gigas adults in México. J Shellfish Res 23:417-419

Voyles BA (2002) The biology of viruses. 2nd edn. McGrawHill Higher Education, New York

> Webb SC, Fidler A, Renault T (2007) Primers for PCR-based detection of ostreid herpes virus-1 (OSH-1): application in a survey of New Zealand mollusks. Aquaculture 272: $126-139$

Submitted: January 18, 2008; Accepted: December 10, 2009 Proofs received from author(s): February 22, 2010 